Információközvetítés és közösségépítés - multifunkciós könyvtári hálózatok. Szerk. Kiszl Péter, Németh Katalin. Budapest, ELTE BTK

Könyvtár- és Információtudományi Intézet. 2020. 55-63.

\title{
KULTÚRA- ÉS INFORMÁCIÓKÖZVETÍTÉS NORVÉG MÓDRA - A TÉNYPRÓZA TÁRSADALOMFORMÁLÓ SZEREPE
}

\author{
ZSÁMBÉKINÉ DOMSA ZsóFIA
}

\section{TARTALMI ÖSSZEFOGLALÓ}

A norvég és svéd nyelven sakprosaként emlegetett szövegek csoportja eredetileg mindenfajta szövegszerü megnyilvánulást magában foglal, ami nem a szépirodalom müfajához sorolható. A magyarra ténypróza kifejezéssel fordított szöveganyag részben a funkcionális szövegeket jelenti, részben pedig az irodalmi ténypróza kategóriájához tartozó szerző által írt, kiadó által megjelentetett és forgalmazott műveket definiálja. A ténypróza tehát olyan szövegekre utal, amelyeket a befogadó a valóságra való direkt utalásként értelmez. A közéleti vitákban ezek a szövegek teremtik a témát, a fogalomrendszert, a gondolkodásmódot, alakítják az őket ismerö közösség világlátását, tehát a modern, nyílt társadalom formálásában rendkívül fontos szerepük van. A norvég tényprózakutatás számos társdiszciplína eszköztárát alkalmazva igyekszik sokrétü tárgyát, a ténypróza demokratikus szerepét megragadni. Tanulmányom célja, hogy ennek a kutatásnak néhány szempontját összefoglaljam, valamint a nemzetközi sikereket elért, illetve nagy feltünést keltett irodalmi tényprózai műveket bemutassam a második világháborútól napjainkig.

A norvég tényprózakutatás szervezett formájában közel harmincéves múltra tekint vissza, de már az 1992-es Norvég Szakírók- és Fordítók Szövetsége által létrehozott kutatási projekt elindulása előtt is az irodalomtörténetírás által számontartott müfajcsoport volt. Az egyik legelső irodalomtörténeti munka, Henrik Jaeger 1896-ban megjelent Illustreret norsk litteraturhistorie ${ }^{1}$ (Képes norvég irodalomtörténet) címü müvében még nem használta a sakprosa kifejezést, de 306 oldalon, külön függelékben tárgyalja a tudományos prózai műveket $A$ 19. század tudományos irodalma címmel. A később megjelenő irodalomtörténetek azonban összemossák és bizonyos tekintetben láthatatlanná is teszik a tényprózához tartozó jelentős műveket, ezzel azt az általánossá vált alapvetést igazolva, hogy az irodalom egyenlö a szépirodalommal. Az 1992-ben alapított kutatócsoport célja többek közt a ténypróza társadalomformáló szerepének felmutatása volt, más szóval a ténypróza láthatóvá tétele. ${ }^{2}$ A kutatócsoport megalakulása óta számos tényprózával foglalkozó antológia, monográfia, történeti munka jelent meg$^{3}$, a terület önálló, open access folyóirattal rendelkezik, Norvégia három legrégebbi egyetemén, az oslói, a bergeni és a trondheimi egyetemen is működik szövegkutató vagy ténypróza tanszék, Sakbib címmel pedig átfogó ténypróza bibliográfia olvasható az interneten. A norvég tényprózakutatás hátteréről érdemes továbbá megjegyezni, 


\section{ZsÁmbÉKInÉ Domsa ZsófiA}

hogy a kutatást támogató Norvég Szakírók- és Fordítók Szövetsége a szakszövegekre vonatkozó magas jogdíjaknak köszönhetően anyagilag a legerősebb szakmai szervezetek közé tartozik az északi országban.

Még mielőtt azonban ennek az interdiszciplináris kutatásnak az eredményeiről és számunkra is hasznosítható tapasztalatairól írnék, szeretném a ténypróza fogalmát tisztázni. Magyar nyelven ugyanis az értekező próza, illetve az értekezés kifejezés szerepel megközelítőleg azonos tartalommal a középiskolai tananyagban, pontos meghatározást azonban nehéz találni róla. Általában a Pallas Nagy Lexikona 1800-as évek végi normatív definíciójának parafrázisa olvasható az érettségire felkészítő anyagokban. A lexikon rövid szócikkének lényege, hogy az értekezés egy tudományos kérdés szakszerü, de nem a teljesség igényével íródó tárgyalása. Stílusát tekintve az értekező prózára szakszerüség és szabatosság jellemző, fogalmazásmódja érdekes, de nem személyes vagy költői. ${ }^{4}$ Müfajai közt a kritika, az esszé és a tudományos disszertáció kerül említésre.

A norvég irodalomkutatás ennél sokkal tágabb müfaji keretben gondolkodik az értekező próza kapcsán és a tudományos irodalmon kívül a kézikönyveket, tankönyveket, útikönyveket, reklámok szövegét, esszéket, lexikonokat, újság- és folyóiratcikkeket, vitairodalmat, történelmi müveket, életrajzokat, de a blogbejegyzéseket, használati utasításokat, utcanév táblákat, az államháztartási beszámolókat és a törvények szövegét is ide sorolja. A kutatás alapul veszi, hogy a szépirodalom vitathatatlan társadalomformáló szerepén túl ezeknek a müveknek jelentősebb hatása van a norvég közélet alakításában, mint az a korábbi kutatásokból kiderül.

Írásomban ennek az igen szerteágazó prózai műfajnak a ténypróza nevet adtam, hogy elkerüljem a kizárólag tudományos jellegű tanulmányokkal való azonosítást. Azért fontos elvenni az egyenlőségjelet a szakirodalom és az értekező próza közül, mert tézisem szerint az egyetemi kutatók számára a szakmai karrier feltételéül szolgáló publikációk, akadémiai, egyetemi tudományos munkák túlnyomó része elenyésző társadalomformáló szereppel bír, míg a ténypróza gyűjtőnéven tárgyalt műfajok a kimondott szó és a kinyomtatott szövegek erőterében alakuló társadalmi nyilvánosság nagyobb hangsúllyal rendelkező tényezői.

Norvégiában és Svédországban a ténypróza kutatása jóval előbbre jár, mint máshol Európában, így Magyarországon is. Ennek ellenére nem az a célom, hogy „bezzeg” példaként emlegessem az észak-európai irodalomszociológiai kutatást, hanem hogy a fontosabb elemzési szempontok és eredmények felmutatásával a humaniora és intézményrendszerei, többek közt az egyetemi, a könyvkiadói és könyvtári hálózat kulturális közvetítő szerepének a hagyományostól némileg eltérő megközelítését javasoljam.

\section{A ténypróza meghatározási módjai}

A ténypróza, norvégul és svédül sakprosa szakkifejezést mindössze nyolcvan éve használja az észak-európai irodalomkutatás. ${ }^{5}$ A különböző összefüggésekben, és különféle 
jelentéstartalommal használt terminust az oktatás, a könyvkiadás, a kultúrpolitika és a tömegkommunikáció a maga sajátos módján alkalmazza. A tényprózakutatás emiatt nem történelemfeletti, stabil jelenségként értelmezi a tényprózát, hanem egy bizonyos gyüjtőfogalomként, amely a szépirodalomhoz nem sorolt müveket jellemzi. A kutatás, mint láttuk, nem korlátozódik a hivatalos szerzők által írt és kiadók által megjelentetett munkákra, hanem az úgynevezett kollektív-intézményi szövegeket is ideérti.

A ténypróza tehát tágabb értelemben olyan szövegekre utal, amelyeket „a befogadó a valóságra való direkt utalásként értelmez." ${ }^{6} \mathrm{~A}$ ténypróza ezen belül két nagyobb alcsoportra bontható: az irodalmi tényprózára, amely alatt „néven nevezett szerzők kiadók által megjelentetett szövegeit" értjük és a funkcionális tényprózára, amely „nyilvánosan hozzáférhető szövegek, melyeket magán vagy hivatalos intézmények alkottak, vagy nevesített, illetve nem nevesített magánszemélyek írtak.” A tágabb értelmezés a nem írásos megnyilvánulásokat is a ténypróza fogalmához sorolja, és a hordozók tekintetében sem szűkíti a kört a nyomtatott szövegekre, hanem az internet, a televízió, a rádió szövegeit is itt tárgyalja.

A tényprózakutatás egy másik fontos kiindulópontja a „szövegkultúra” ${ }^{\text {fo- }}$ galma, amelyet egyszerüen úgy fogalmazhatunk meg, hogy „emberek azon csoportja, akik szövegek révén egy bizonyos mértékig közös normarendszer alapján kommunikálnak egymással."9 Angol terminusként a discourse community kifejezést használhatnánk a jelenség megragadására, bár a diskurzus tágabb kifejezés, míg a közösség jóval szűkebb, mint amit a szövegkultúra megfogalmazás rejt. A szövegkultúrán belül bizonyos konvenciók, normák érvényesek, amelyek a megnyilatkozások megformálására vonatkoznak, és annak feltételrendszerét adják meg, hogy miként illeszkedhet a megnyilatkozás az adott szövegkultúrába, tehát miként adhat át értelmes üzenetet. Így például a kívülállók által kiolvashatatlan falfirkák a graffiti-közösség tagjai számára értelemmel bíró üzenetek. ${ }^{10}$

A tényprózakutatás egyik alapvető sajátossága tehát, hogy a szöveget a kontextusával együtt vizsgálja, de sem a szöveget, sem a szövegösszefüggést nem tekinti állandónak. Az írott ténypróza dinamikus, a modern párbeszédelemzéshez fogható vizsgálata ugyanis magába foglalja a szöveg kortárs közegét és előzményeit, valamint azt, hogy miként teremt a szöveg folyamatosan új kontextust.

A tényprózakutatás nem törekszik egységes elmélet kialakítására, elméleti megközelítésében ezért számos modern tudományág képez interdiszciplináris referenciát. A szemiotika, a funkcionális nyelvészet, a bahtyini többszólamú szövegelemzés, a könyvtörténet mellett a retorikai hagyományra támaszkodik a kutatás. A meggyözés ismert retorikai triásza, az ethos, logos és pathos hasonlít a tényprózakutatásban megfigyelt eszköztárra, bár nem teljesen azonos vele. Az ethos és a logos révén a szövegben rejlő beszélő iránti bizalom alakul ki, amely elsősorban az író, szónok, újságíró meggyőző szakmai tudásán alapszik. A ténypróza írás alapfeltétele ugyanis a szaktudás. Ugyanakkor a harmadik retorikai kulcsfogalom, a pathos sem elhanyagolható, 


\section{ZsÁmbÉKInÉ Domsa ZsófiA}

annak ellenére, hogy a ténypróza alapvetően nem patetikus. Rolf Pipping, a finn svéd filológus, aki a kifejezést megalkotta, annak idején így fogalmazott a ténypróza stílusát illetően: „Az érzelmek elvből kizárva." ${ }^{11} \mathrm{Ez}$ a kitétel később béklyóvá vált, amely alól a tényprózakutatás igyekszik a ténypróza szövegeket felmenteni, mondván, hogy Pipping kora terjengős stílusú írásmódjával szemben a tényszerűség ideáját tűzte ki célul az érzelmek kikapcsolása mellett. Pipping meglátását cáfolja az olvasói tapasztalat, amely szerint a pathos nélküli irodalmi szöveg minden bizonnyal olvashatatlan volna. ${ }^{12} \mathrm{~A}$ retorikai triász mellett a kairos fogalom bukkan fel gyakran a tényprózaelemzésekben, amely eredetileg a megfelelő pillanat, modern értelemben a megfelelő kontextus megválasztását jelenti.

A ténypróza meghatározására természetesen nemcsak a fent idézett valósághoz direkt módon viszonyuló megközelítés létezik ${ }^{13}$, mégis ennél szeretnék maradni, mivel ez a meghatározás az olvasóval kötött íratlan szerződésre is utal. A szerződés a különböző olvasói magatartásra vonatkozik, amellyel mondjuk egy második világháborús történelmi regényt és egy világháború történetéről szóló tudományos munkát közelítünk meg. Látni fogjuk, hogy a példaként felhozott norvég müvek esetében ennek a szerződésnek jelentős szerepe lesz.

A konkrét példák előtt azonban a norvég tényprózakutatásról záró gondolatként érdemes megjegyezni, hogy nemcsak tudományos munkák, konferenciák és a „megélhetési” filológia számos egyéb formája köszönheti ennek létezését, hanem a norvég állami íráskultúra fokozatos reformja is részben ehhez a kutatáshoz köthető. Klartspråk i Staten (Közérthető közigazgatás) lett a hivatalos megnevezése annak a 2009-ben indult projektnek, amelynek célja az írásos és szóbeli kommunikáció egyszerüsítése és közérthetővé tétele. A közigazgatási szövegek megértése ugyanis elvileg nem csak a jogászok, közgazdászok, hivatalnokok dolga, hanem a multikulturális norvég társadalom minden tagjáé. Johann Tønnesson a tényprózakutatás professzora a ténypróza demokratikus szerepét hangsúlyozza. Rolf Pippingre hivatkozva jegyzi meg, hogy a finn svéd kutató munkáját is az motiválta, miként tudná a tényszerü íráskultúrát a demokrácia megerősítésének érdekében előmozdítani. ${ }^{14} \mathrm{~A}$ társadalom fejlődése érdekében folyton új tudásra, új ötletekre van szükség, és mindez nem a szépirodalomban, hanem ténypróza formájában jelenik meg. Egy ország polgárai ténypróza szövegek révén, így például újságcikkek, kommentek, posztok formájában vitathatják meg, miként vannak a dolgok és miben kellene másképp lenniük. Mivel, mint láttuk, számtalan tényprózaműfaj létezik, fontos, hogy több műfajban is jártasak legyünk, hogy értsük a müfaji kritériumokat és forráskritikával forduljunk az elénk táruló szövegmennyiség felé. ${ }^{15} \mathrm{~A}$ tényprózakutatás egyik legfontosabb motiváló tényezője tehát az értő olvasóvá nevelés mind az iskolai oktatásban, mind a humaniorában, mind pedig a közéletben.

A ténypróza kifejezés mára a norvég szókincs bevett fogalma lett. Számos kritikai díj és olvasói szavazás alapján minden évben több tényprózamű kerül a könyveladási listák élére. A ténypróza könyvek népszerüsége a szépirodaloméval vetekszik, 
sőt egyre inkább megfigyelhető, ahogy a két műfaj határán mozgó művek válnak igazán kedveltté, vitatottá vagy úttörővé. A müfaji határátlépést mutatja, hogy a 2019 márciusában a norvég kritikusok díját elnyerö egyetemi professzor, Jan Grue önéletrajzi műve Jeg lever et liv som likner deres (Olyan életet élek, mint a tiétek) a skandináv irodalmi Nobel-díjként emlegetett Északi Tanács Irodalmi díjára is fel volt terjesztve. Ezek a díjak évtizedek óta kizárólag szépirodalmi művek elismerésére szolgáltak, amikor a kerekesszékes Grue gyerekkori orvosi jelentésekre épülö, dokumentarista műve irodalmi értékként lett elismerve. A következőkben néhány olyan irodalmi határátlépésről szeretnék írni, amelyek nagymértékben befolyásolták a norvég társadalom második világháborút követő alakulását, és az ország határain kívül is elismerésre tettek szert.

\section{Ténypróza és irodalom}

Számos lista és rangsor létezik Norvégiában arról, hogy a szakértők, a Norvég Szakírók- és Fordítók Szövetsége, a kritikusok és az olvasók miként látják, mely az irodalmi ténypróza területéhez tartozó művek hatottak leginkább a modern norvég közéletre. Számos müfaji alkategória is létezik, amelyek közül a tankönyvek, gyermekkönyvek nehezebben kerülnek ki a világ könyvpiacára, mint az ismeretterjesztő, tudományos vagy történelmi müvek. A 2019-es XXVI. Budapesti Nemzetközi Könyvfesztivál díszvendég országa Norvégia volt, a fesztiválon bemutatott könyvtermés több mint fele tényprózai mű volt. Az író díszvendég, Karl Ove Knausgård pedig több ezer oldalas, hatkötetes önéletrajzi regénye miatt került a világirodalmi ranglisták élére. A dokumentarizmus és széppróza határait végletekig feszítő, számos hazai és nemzetközi botrányt kiváltó Harcom (2009-2011) megkerülhetetlen példa arra, ahogy az irodalom, legyen az fiktív vagy tényszerü, megváltoztatja, átírja azt a kontextust, azt az irodalmi normarendszert, amelyben íródik. Nemcsak a hagyományos olvasói szerződések megmásításáról van szó (ld. Poul Behrendt dobbeltkontrakt, azaz kettős szerződés kifejezését ${ }^{16}$ ), hanem arról is, ahogy a könyv első kötetei körüli médiabotrány az utolsó kötet témájává válik. A közélet és irodalom ilyen gyors visszacsatolása páratlan az európai irodalomban és nyilvánvalóan egy új irodalomfelfogást eredményez a hivatásos olvasók és a laikusok körében is.

A második világháború norvég irodalmi kánon ténypróza listáját egy országos napilap, a Dagbladet alkotta meg 2008-ban. ${ }^{17}$ 2017-ben is indult hasonló kezdeményezés, a norvég állami televízió- és rádiótársaság és a Norvég Szakírók és Fordítók Szövetségének együttmüködésével, külön müfaji kategóriákban tárgyalva az esélyes jelölteket. A közéletet befolyásoló művek közt szerepelnek olyan művek, mint Jens Arup Sveip esszéje Fra embedsmannsstat til ettpartistat (Hivatalnokállamtól az egypártrendszerig, 1963), amely történelmi modellek alkalmazását honosította meg a szaktudományos prózában, míg Rune Slagstad: De nasjonale strateger (Nemzeti stratégák, 1998) címü 


\section{ZsÁmbÉKInÉ Domsa ZsófiA}

műve a norvég közélet modernizálódási folyamatait tárgyalja a bevett nézetrendszertől eltérő módon 1814-től, 1990-ig. Megkerülhetetlen fontosságú mű Georg Johannesen: Om den norske tenkemåten (A norvég gondolkodásmódról) címü, 1975-ben megjelent esszé- és cikkantológiája, amelyben az irodalom és a politika problémáit vitatja a norvég legismertebb esszéistája, a dialektikus gondolkodás példatárát biztosítva a következő három generáció számára. A norvég történelem és társadalom ismerői számára ezek a művek különös jelentőséggel bírnak, jelen keretek közt inkább néhány nemzetközileg is ismert müről szeretnék röviden írni.

A norvég néprajzkutató, Thor Heyerdahl Kon-Tiki expedíciójáról készült könyv és dokumentumfilm világhíressé tette a felfedezőt. Heyerdahl a gyakorlatban bizonyította a Polinézia benépesítésével kapcsolatos elméleti feltevések téves voltát, amikor balsafából készült tutaján, nemzetközi legénységével átkelt a Csendes-óceánon. Munkája a világháború utáni Amerikában és Európában népszerüvé tette a néprajzot, a Kon-Tiki címü, 1948-ban megjelent könyv a tudományos ismeretterjesztés alapvető fontosságú műve lett a nemzetközi kánonban. Hetven nyelvre, köztük magyarra is lefordították, és Tutajjal a Csendes-óceánon címmel adták ki 1962-ben (Gondolat, ford. Istványi Ernő). A film 1950-ben elnyerte az Oscar-díjat a legjobb dokumentumfilm kategóriában.

Bár Thor Heyerdahl is botrányt váltott ki, különösen az északi istenek és vallás közel-keleti gyökereire vonatkozó Jakten på Odin (Odin nyomában) címü, 2001-ben megjelent tanulmányával, de a legnagyobb felháborodást és társadalmi vitát a müfaj norvég képviselöi közül Knut Hamsun váltotta ki. Az 1920-ban Nobel-díjjal kitüntetett író, akit elsősorban a Sult (Éhség, 1890) címü regénye miatt a modern irodalom atyjának is szoktak tekinteni, a világháború alatt a Nobel-díját Joseph Goebbelsnek ajánlotta fel, Hitler halálakor pedig nekrológot írt, és a diktátort az „emberiség harcosának" nevezte. Közvetlenül a háború után Hamsun letartóztatásba került, ahol pszichiátriai vizsgálat alá vetették. A cél az idős szerző mentális beszámíthatatlanságának megállapítása volt annak érdekében, hogy a nemzeti irodalmi kincs ne vesszen kárba a németül nem tudó, de a germán kultúra iránt egész életében rajongó magánember eltévelyedése miatt. A 90 éves, szinte teljesen süket Hamsun 1949 szeptemberében megjelentette a På gjengrodde stier (Benőtt ösvényeken, Nagyvilág kiadó, ford. Miszoglád Gábor, 2002) címmel önéletrajzi írását, amely a védőőrizetben töltött idő, a pszichiátriai vizsgálat, a kihallgatások és az ellene folytatott tárgyalás dokumentumregénye. Ebben a szövegben pontos hivatkozások keverednek fiktív elemekkel, s bár a Hamsun-kutatás a teljes életmű tükrében vitatja a szöveg hitelességét, a Benőtt ösvényeken egyértelmüen bizonyítja, hogy Hamsun elméje nem volt zavart, nácizmus iránti vonzalmát nem lehet individuál-pszichológiai alapon magyarázni. Hamsun önéletrajzi írása a fikció és a valóság határán értelmezhetö, és az utókor irodalomtudósai számára nyilvánvalóan ebből a szempontból érdekes, ám a befogadó közeg, a kortárs olvasók számára megrázó és a mai napig nem csituló Hamsun-vita mérföldköve volt. A gyülölt, nácibarát szerzőt bolondnak titulálták, hogy mentsék a nemzeti kincsnek 
KULTÚRA- ÉS INFORMÁCIÓKÖZVETÍTÉS NORVÉG MÓDRA - A TÉNYPRÓZA...

számító életművet, 1952-ben bekövetkezett halála után viszont egyfajta Hamsunreneszánsz zajlott le. A róla szóló diskurzus még mindig nincs, és nyilván nem is lesz nyugvóponton, de a Benőtt ösvényeken mind irodalomtörténetileg, mind társadalmilag sorsfordító jelentőségét nem lehet elvitatni. Mi sem bizonyítja ezt jobban, mint az a tény, hogy a már említett 2017-es rangsorban a kultúra- és szórakoztató irodalom kategóriában Hamsun utolsó regénye nyerte el az első helyet.

Szintén a fenti versenyben, a gyermek- és ifjúsági tényprózában első helyen végzett Jostein Gaarder Sofies verden (Sofie világa, Pesti Szalon Kiadó, 1995, ford. Szöllősi Adrienne) címü, 1991-ben megjelent filozófiatörténeti regénye, amelyet 64 nyelvre fordítottak le eddig, és több mint 50 millió példányban fogyott el. Gaarder művét nem regénynek szánta, hanem középiskolások számára filozófiatörténeti bevezetésként. Bár sokan állítják, hogy a filozófiai tananyag mögé vagy mellé tett ifúsági regény története nem is fontos, a páratlan nemzetközi sikert azonban nem lehet azzal magyarázni, hogy a kilencvenes években népfőiskolai tanárként dolgozó Gaarder pusztán jól megírt filozófia tankönyvet adott volna ki. A történet ereje is hat, csakúgy, mint az emberi gondolkodás lebilincselő története és az irodalomtudomány által metaszövegként definiált, a fikciót és valóságot összemosó csavar.

Åsne Seierstad: Bokhandleren i Kabul (Kabuli könyvkereskedő) című müve 2002-ben jelent meg és szintén bestseller lett a The New York Times szerint 41 héten keresztül. A háborús- és konfliktusövezetben riporterként az emberek hétköznapjait megörökítő írónő ténypróza könyve egy kabuli könyvkereskedő családi drámáját mutatja be kendőzetlen őszinteséggel. A résztvevő megfigyelés módszerével készült szöveg az ábrázolt szereplők lelkivilágát is ábrázolja, megkérdőjelezve a szöveg objektivitását. Mégsem ez a pszichiátriában is gyakran alkalmazott diagnosztizálási mód, illetve a fikció és valóság összemosása tette híressé a könyvet és szerzőjét, hanem a könyv címszereplője által indított polgári per, amelyet első fokon Shah Mohammed Rais meg is nyert az írónő ellen, magánéletének megsértése miatt. A Kabuli könyvkereskedő a modern nyugati társadalom elé tárt többé-kevésbé hitelesen egy olyan zárt világot, amelyben a nemi szerepek egy egészen más kultúra szabályainak alárendelve müködtek és működnek ma is. Seierstad azóta megírta a Breivik-biográfiát (En av oss, Közülünk való 2013), amely a 2011. július 22-i terrortámadások hátterét beszéli el. 2016-ban jelent meg a To søstre (Két nővér) címet viselő oknyomozó riportkönyve, amely az IS-hez önként csatlakozó két norvég lány életéről számol be. Seierstad tényprózája ugyan vitatható abból a szempontból, hogy jellegzetesen szépirodalmi eszközt használ, mikor főszereplői gondolatait közvetíti, művei mégis inkább tényprózához sorolhatók, nem utolsósorban azért, mert a kortárs közéletet foglalkoztató témákat boncolnak, vitára, hozzászólásra ösztönözve a társadalmat.

Míg Seierstad müvei sajnos nem olvashatók magyar nyelven, Morten A. Strøksnes Havboka címü, 2015-ben megjelent lebilincselő műve Szöllősi Adrienne kiváló fordításában magyarul is élvezhető. ${ }^{18}$ Bár a Tengerkönyvet is átszövik az önéletrajzi fo- 


\section{ZsÁmbÉKInÉ Domsa ZsófiA}

nalak, s a mü főszereplőjének gondolatai és érzelemvilága ugyanúgy kerül fókuszba, ahogy a szépirodalmi művek esetében ábrázolt alakok, a hangsúly a szövegben rejlő rendkívüli tudásanyagról, az óceánok múltjáról és jövőéről, az embereknek a tengerek mélyén élő titokzatos és furcsa lényekhez füződő évezredes viszonyáról, a környezetkárosító tevékenységek visszafordíthatatlan következményeiről. Több ezer oldalnyi szakirodalmat kellene ahhoz az olvasónak átolvasnia, hogy mindezt az elképesztően érdekes tudást birtokában tudhassa. Strøksnes könyve azonban nem öncélúan sürít ennyi tudást egy grönlandi cápa kifogásának banális történetébe, szándékosan kívánja figyelmünket a szárazföldről a tengerek felé irányítani, olyan perspektívaváltást okozva, amely a klímaváltozásban kételkedőket is környezetvédő aktivistává formálja.

A ténypróza a norvég demokrácia, a társadalmi közbeszéd alapja, hangzott a tényprózakutatás egyik legfontosabb alapvetése. A megállapítás elsősorban a ténypróza funkcionális területeire: a törvények szövegére, a választási kampányok mondataira, a hivatalos levelek megfogalmazásaira, vagy akár az utcatáblákra vonatkozott. Mindezen műfajok importja nehezebben lehetséges, mint az írásom második felében tárgyalt irodalmi ténypróza norvég határokon túl is sikert és elismerést aratott müveinek alapos megismerése. Érdekes megjegyezni, hogy az említett müvek a webes könyváruházak „egyéb” kategóriájához sorolódnak, jelezve a magyar terminológiai hiányosságot. A norvég ténypróza jeles irodalmi műveinek adaptálása után, remélhetőleg a tényprózakutatás módszertana és terminus technicusai is átvehetők lesznek a magyar irodalomszociológia és kultúratudomány számára.

\section{Irodalom és jegyzetek}

1. JAEGER, Henrik: Illustreret norsk litteraturhistorie. Kristiania, Hjalmar Biglers forlag, 1896.

2. ERIKSEN, Trond Berg: Norsksakprosa - strategiogerfaringer. In: Børre Johnsen, Egil (red.): Forbildets forbilder. Norsk sakprosa. Andre bok. Oslo, Universitetsforlaget, 1996. 261. p.

3. Fontos megemlíteni két kötetet: Norsk litteraturhistorie. Sakprosa fra 1750 til 1995 (Eriksen og Johnsen, Oslo, Universitetsforlaget, 1998.) és az elméleti alapmü: Det littercere skattkammer. Sakprosaens teori og retorikk (Grepstad, Oslo, Norsk faglitterær forfatterogoversetterforening, 1997.)

4. Pallas Nagy Lexikona. Forrás: http://mek.oszk.hu/00000/00060/html/033/pc003306. html\#4 [2019. június 20.]

5. PIPPING, Rolf: Språk och stil. = Finsk tidskrift, nr. 10. 1938. 202-214., 267-276., 272. p.

6. TØNNESSON, Johan: Hvaer sakprosa? Oslo, Universitetsforlaget, 2008. 34. p.

7. Uo.

8. BERGE, Kjell Lars: Det vitenskapelige studiet av sakprosa. Om tekstvitenskapelige utfordringer og løsninger i norsk og svensk sakprosaforskning. In: Berge, Kjell Lars et.al.: Fire blikk på sakprosaen. INL, Universitetet i Oslo, 2001. = Prosjektmiljøet Norsk 
KULTÚRA- ÉS INFORMÁCIÓKÖZVETÍTÉS NORVÉG MÓDRA - A TÉNYPRÓZA...

sakprosa, skrift, nr. 1. 9-74. p. Forrás: http://www.hf.uio.no/iln/forskning/grupper/ tekstretorikk/skriftserien/utgivelser/1Berge-Breivega-Roksvold-Tonnesson-Fire-blikkpa-sakprosa.pdf [2019. április 12.]

9. TØNNESSON, Johan L.: Hvaer sakprosa? Oslo, Universitetsforlaget, 2008. 58. p.

10. TØNNESSON, Johan L. - BERGE, Kjell Lars: Forskningen om sakens prosa. = Sakprosa, vol. 1. nr. 1. 2009. Art. 1. 2-12. p. Forrás: https://doi.org/10.5617/sakprosa.32 [2019. június 25.]

11. PIPPING, Rolf 1938: Språk och stil. = Finsk tidskrift, nr. 10. 1938. 272. p.

12. TØNNESSON, Johan L. - BERGE, Kjell Lars: i. m. 7-12. p. Forrás: https://doi.org/10.5617/ sakprosa.32 [2019. június 25.]

13. Egy másik közismert meghatározás a Detlitterceskattkammer. Sakprosaens teori og retorikk címü müben olvasható (Grepstad, Oslo, Norsk faglitterær forfatter- og oversetterforening, 1997). Lényegét tekintve ez a definíció azonban nem teszi lehetővé a szépirodalom és a ténypróza különválasztását, ezért nem célszerü e tanulmány keretei közt foglalkozni vele.

14. TØNNESSON, Johan L.: Sakprosa. In: Store norske leksikon. Forrás: https://snl.no/ sakprosa [2019. június 21.]

15. Uo.

16. BEHRENDT, Poul: Dobbeltkontrakten. København, Gyldendal, 2006.

17. ANKER, Peder: Hererbøkene som virkeligendret Norge. Sakprosa-debattenfortsetter. = Dagbladet, 2008. 08. 08. Forrás: https://www.dagbladet.no/kultur/her-er-bokene-somvirkelig-endret-norge/66507426 [2019. június 25.]

18. STRØKSNES, Morten A.: Tengerkönyv - Sós történet barátságról, kalandról és a felszín alatt nyüzsgő életről. Budapest, Jelenkor, 2018.

Zsámbékiné Domsa Zsófia az ELTE BTK Germanisztika Intézetében a Skandináv Nyelvek és Irodalmak Tanszék egyetemi adjunktusa. Kutatási területe a skandináv irodalomtörténet, norvég irodalomtörténet, irodalomtudomány, óészaki irodalom és skandináv drámairodalom. ORCID: 0000-0001-6472-1913 